\title{
Alterations in Hematological and Serum Biochemical Parameters of Sahel Goats with Clinical Mastitis
}

\author{
${ }^{1}$ Yusuf Abba. ${ }^{1}$ Ikechuckwu Oyebuchi Igbokwe; ${ }^{2}$ Lawan Adamu and \\ ${ }^{1}$ Ibrahim Buba \\ ${ }^{1}$ Department of Veterinary Pathology, Faculty of Veterinary Medicine, University of Maiduguri, P.M.B. 1069, \\ Maiduguri, Borno State, Nigeria \\ ${ }^{2}$ Department of Veterinary Medicine, Faculty of Veterinary Medicine, University of Maiduguri, P.M.B. 1069, \\ Maiduguri, Borno State, Nigeria
}

\begin{abstract}
Mastitis is a widespread disease of the dairy goats associated with alterations in the physical, chemical, pathological and bacteriological quality of milk and glandular tissues. Therefore, the aim of the present study was to evaluate the effect of clinical mastitis on hematological and serum biochemical parameters of Sahel Goats in Nigeria. Twenty six Sahel goats with clinical mastitis and ten normal goats taken as the control group were used for the study. Blood samples were collected via the jugular vein for hematological and biochemical analysis. A significant increase $(p<0.05)$ in neutrophil count and a significant decrease $(p<0.05)$ in lymphocyte and eosinophil counts were observed in the goats with clinical mastitis. However, changes observed in the total red blood cell count, packed cell volume and hemoglobin concentrations were within the normal reference values. Serum levels of $\mathrm{Na}^{+}, \mathrm{Cl}$ and $\mathrm{HCO}_{3}^{--}$were significantly lower $(p<0.05)$ in Sahel goats with clinical mastitis compared to the control group. There were no significant differences in total protein, albumin, globulin and serum $K^{+}$concentrations in the Sahel goats with clinical mastitis compared to the control group. The alterations observed in the hematological and biochemical parameters in the Sahel goats with clinical mastitis could be due to altered quality of milk as a result of the physical, pathological, bacteriological and glandular changes.
\end{abstract}

Key words: Clinical mastitis, Hematological, Serum biochemical, Sahel goat

\section{Introduction}

Mastitis is a universal disease of the dairy goats accompanied by physical, chemical, pathological and bacteriological changes in milk and glandular tissues [1-2]. The course of the disease in goats ranges from acute to chronic [3], and is characterized by deterioration of the physical condition, pneumonia, septicemia, and sometimes toxemia [4]. The disease is caused by several microbial agents such as Staphylococcus aureus, Escherichia coli, and Clostridium perfringens, yeast and fungi [5, 2, 6-11]. Mastitis in goats is a fatal clinical form associated with inflammatory processes in the mammary glands [12]. The responses in tissues are mostly associated with exudations and cellular infiltration which alter blood cellular counts [13-16]. Serum biochemical changes are of paramount importance in accessing the level of cellular and systemic responses of tissues and organs to damage.

To the best of the author's knowledge, the relationships between mastitis, hematological and biochemical alterations are lacking in Sahel goats. The aim of the present study was to evaluate the alterations in hematological and serum biochemical parameters of Sahel Goats with clinical mastitis.

\section{Materials and methods}

Twenty six Sahel goats with clinical mastitis and ten normal goats taken as the control group between the ages of 3.5 years were used for the study. The mammary glands of the goats were examined and clinical mastitis was defined based on physical examination of the gland by palpation and examination of expressed milk for abnormal color and consistency. Sampling: Blood samples were obtained from all goats via the jugular vein, anticoagulated with Ethyl Diaminotetra-Acetic Acid (EDTA) for hematological analysis and lithium heparin for biochemical analysis. The hematological parameters determined were erythrocyte, leucocyte counts and hemoglobin concentration using (Cell DYN 3700, Abbot) and hematocrit (PCV) using (Hettich-Hematocrit 210 and Hawksley microhematocrit reader) and differential leucocyte count. The plasma electrolyte and biochemical, sodium, potassium, chloride, total protein, albumin and globulin concentrations were determined by chemistry analyser (Hitachi 920) using standard diagnostic kits (Roche).

The data were analyzed using t-test with the statistical software package JMP 9 (SAS, QSAS Institute Inc, Cary, NC, USA). Analyses were considered as significant at $\mathrm{p}<.05$. 


\section{Results}

The red blood cell counts, packed cell volume, neutrophil counts, lymphocyte and eosinophil counts were all affected in goats with clinical mastitis, while $\mathrm{Hb}, \mathrm{WBC}, \mathrm{MCV}, \mathrm{MCH}, \mathrm{MCHC}$ and monocytes were unaffected in the clinical mastitis group and the control group. However, there was a significant increase $(p<0.05)$ in the neutrophil count and a significant decrease $(p<0.05)$ in differential lymphocyte and eosinophil counts in goats with clinical mastitis (Table 1). Serum biochemical evaluations showed a significant decrease $(\mathrm{p}<0.05)$ in $\mathrm{Na}^{+}, \mathrm{Cl}^{-}$and $\mathrm{Hco}_{3}{ }^{-}$(Table 2). However, no changes were observed with regard to total protein, albumin and globulin concentrations in the serum.

Table 1: Hematological parameters of Normal and clinical mastitis goats

\begin{tabular}{|c|c|c|}
\hline parameters & Normal goats $(n=10)$ & Clinical mastitis goats $(n=26)$ \\
\hline PCV (\%) & $33.25^{\mathrm{a}} \pm 7.11$ & $28.67^{b} \pm 4.13$ \\
\hline $\mathrm{Hb}(\mathrm{g} / \mathrm{dl})$ & $12.24^{\mathrm{a}} \pm 2.41$ & $10.70^{\mathrm{a}} \pm 1.77$ \\
\hline $\mathrm{WBC}\left(\times 10^{3} / \mu \mathrm{l}\right)$ & $10.59^{\mathrm{a}} \pm 1.56$ & $9.90^{\mathrm{a}} \pm 1.64$ \\
\hline $\mathrm{RBC}\left(\times 10^{6} / \mu \mathrm{l}\right)$ & $15.27^{\mathrm{a}} \pm 2.60$ & $13.29^{\mathbf{b}} \pm 3.15$ \\
\hline $\mathrm{MCV}(\mathrm{fl})$ & $21.81^{\mathrm{a}} \pm 2.84$ & $22.34^{\mathrm{a}} \pm 2.64$ \\
\hline $\mathrm{MCH}(\mathrm{pg})$ & $7.99^{\mathrm{a}} \pm 0.82$ & $8.16^{\mathrm{a}} \pm 0.85$ \\
\hline $\operatorname{MCHC}(\mathrm{g} / \mathrm{dl})$ & $36.89^{\mathrm{a}} \pm 2.18$ & $36.64^{\mathrm{a}} \pm 2.07$ \\
\hline Neutrophil $\left(\times 10^{3} / \mathrm{ul}\right)$ & $3.95^{\mathrm{a}} \pm 1.08$ & $4.71^{b} \pm 0.77$ \\
\hline Lymphocyte (x10 $3 / \mathrm{ul})$ & $5.56^{\mathrm{a}} \pm 0.99$ & $4.78^{\mathbf{b}} \pm 0.68$ \\
\hline Monocyte (x103/ul) & $0.17^{\mathrm{a}} \pm 0.15$ & $0.11^{\mathrm{a}} \pm 0.08$ \\
\hline Eosinophil $\left(\mathrm{x} 10^{3} / \mathrm{ul}\right)$ & $0.61^{\mathrm{a}} \pm 0.26$ & $0.29^{\mathbf{b}} \pm 0.13$ \\
\hline
\end{tabular}

a, $b$ Means with different superscripts are significantly different $(p<0.05)$

Table 2: Biochemical parameters of Normal and clinical mastitis goats

\begin{tabular}{|c|c|c|}
\hline parameters & Normal goats $(n=10)$ & Clinical mastitis goats $(n=26)$ \\
\hline $\mathrm{Na}^{+}(\mathrm{mmol} / \mathrm{l})$ & $138.3^{\mathrm{a}} \pm 1.77$ & $136.5^{b} \pm 2.08$ \\
\hline $\mathrm{K}^{+}(\mathrm{mmol} / \mathrm{l})$ & $4.7^{\mathrm{a}} \pm 0.68$ & $5.2^{\mathrm{a}} \pm 0.90$ \\
\hline $\mathrm{Cl}^{-}(\mathrm{mmol} / \mathrm{l})$ & $100.4^{\mathrm{a}} \pm 2.10$ & $98.4^{b} \pm 2.26$ \\
\hline $\mathrm{Hco}_{3}^{-}(\mathrm{mmol} / \mathrm{l})$ & $20.5^{\mathrm{a}} \pm 0.53$ & $19.4^{\mathrm{b}} \pm 1.17$ \\
\hline Total protein $(\mathrm{g} / \mathrm{dl})$ & $75.0^{\mathrm{a}} \pm 10.22$ & $72.2^{\mathrm{a}} \pm 9.60$ \\
\hline Albumin (g/dl) & $32.6^{a} \pm 4.10$ & $33.0^{\mathrm{a}} \pm 3.50$ \\
\hline Globulin (g/dl) & $42.4^{\mathrm{a}} \pm 12.04$ & $39.2^{\mathrm{a}} \pm 9.28$ \\
\hline
\end{tabular}

a, $b$ Means with different superscripts are significantly different $(\mathrm{p}<0.05)$

\section{Discussion}

Hematological values determined for clinical mastitis goats in the present study showed a significant increase in neutrophil and a decrease in lymphocyte and eosinophil counts. The significant changes observed between the clinical mastitis group and the control group could be due to the degree of inflammatory responses at the systemic levels. The findings in the present study, is similar to the study conducted by [17-18]. In the current study, increased value of neutrophils indicates chemotactic factors released by the infectious agents and other immune system components that signal for the recruitment of neutrophil to the sites of infection. Though, the incursion of neutrophils is a dual mechanism. This may cause an inflammatory reaction that results in the elimination of infection and also tissue injury that may lead to fibrosis and impaired mammary function [19, 31], this occurrence is obvious in the current study where goats afflicted with clinical mastitis had fibrosis and impaired mammary function. Neutrophils promote tissue injury and disturb mammary function and granular enzyme release responsible for tissue degranulation [20-21]. These findings are in accord to the findings of the present study. In the current study, the lack of significance differences between the clinical mastitis group and the control group in the values of $\mathrm{MCH}, \mathrm{MCV}$ and $\mathrm{MCHC}$ could be due to lack of shift in the erythrocyte population in the two groups; and the mean values of $\mathrm{MCV}, \mathrm{MCH}$ and $\mathrm{MCHC}$ could decrease with respect to time but the reduction may vary following suckling processes. The present finding is similar to the study carried out by [22]. Similarly, there were no significant differences between the goats with clinical mastitis and the control group in the values of total WBC and monocytes. The lack of significant differences in these groups could be attributed to the phase and progression of the disease as reported by [23].

In the current study, there were significant decreases in the values of packed cell volume and total red blood cells count between goats with clinical mastitis and the control group while; there were significant decreases in lymphocytes and eosinophils count and a significant increase in neutrophils count between the goats with clinical mastitis and the control group. These findings were similar to the findings of [10] where the workers observed a decrease in total erythrocyte count and an increase in total and differential leucocyte counts 
in goats with clinical mastitis in Oyo State Nigeria. Erythrocyte and leukocyte counts could be important determinants for accessing responses in systemic tissue injury. Depending on the stage and type of inflammation present, the cellular response in the blood could also vary [24-13].

In the present study, serum biochemical evaluations showed significant decrease in $\mathrm{Na}^{+}, \mathrm{Cl}^{-}$and $\mathrm{HCO}_{3}{ }^{-}$ ions. The decrease in the concentrations of the electrolytes in the clinical mastitis group could be due to the onset of the disease. According to $[25,26,30]$ milk in normal goats contains high concentrations of electrolytes particularly potassium and chloride. However, no differences were observed with regard to total protein, albumin and globulin concentrations in the serum [27]. Albumin constitutes the major protein fraction in blood and tends to be decreased during inflammatory processes [28-29].

In conclusion, the results of this finding indicate that clinical mastitis in the Sahel goats' results in significant fluctuations in hematological and serum biochemical parameters. The alterations could be due to altered quality of milk as a result of the physical, pathological, bacteriological and glandular changes.

\section{Acknowledgement}

We wish to acknowledge Mal Ismail Ahmed Gadaka of the Clinical Pathology laboratory, Faculty of Veterinary Medicine, University of Maiduguri for his assistance during the research.

\section{References}

[1] Radostits, O. M, Arundel. J. U and Gay. C. C. (2000): Veterinary Medicine: A textbook of diseases of cattle, sheep, pigs, goats and horses. Elsevier Health Sciences, United Kingdom. Ninth Edition, pp 87-92

[2] Ameh, J. A, Addo, P. B, Adekeye, J.O and Gyang, E. O. (1993): Prevalence of clinical mastitis and intramammary infections in Nigerian goats. Preventive Veterinary Medicine, 17(1-2):41-46.

[3] Acland, H.M. (1995): Male reproductive system: In Thompson's Special Veterinary Pathology. Carlton, W.W and Mc Gavin, M.D (eds). Mosby University Graphic Production, Missouri, U.S.A. Second Edition, pp 544-560.

[4] Cable CS, Peery K, Fubini SL. Radical mastectomy in 20 ruminants. Vet Surg. (2004); 33(3):263-266. Doi: 10.1111/j.1532950X.2004.04038.x.

[5] DaMassa, A. J. (1983): Recovery of Mycoplasma agalactiae from mastitic goat milk. J Am Vet Med Assoc, 183(5):548-549.

[6] Egwu, G.O., Zaria, L. T, Onyeyili, P. A., P.A, Ambali, A. G, Adamu, S. S and Birdling, M. (1994): Studies on the microbiological flora of caprine mastitis and antibiotic inhibitory concentrations in Nigeria. Small Ruminant Research, 14(3):233-239.

[7] Ameh, J. A and Tsari, I. S. (1999): Observations on the prevalence of caprine mastitis in relation to predisposing factors in Maiduguri. Small Ruminant Research, 35(1):1-5.

[8] Alawa, J.P, Ngele, M.B and Ogwu, D. (2000): Chronic caprine mastitis in Nigerian goat breeds: microbiological flora and histopathological findings. Small Ruminant Research, 35(3):203-207.

[9] Egwu.G.O, Ameh, J. A., Aliyu, M. M and Mohammed, F. D. (2001): Caprine mycoplasmal mastitis in Nigeria. Small Ruminant Research, 39(1):87-91.

[10] Ajuwape, A.T.P, Roberts. A.A, Solarin, O.O and Adetosoye, A .I (2005): Bacteriological and hematological stu dies of clinical mastitis in goats in Ibadan, Oyo state, Nigeria. Small Ruminant Research, 60(3):307-310.

[11] Wael M. El-Deeb. 2013. Clinicobiochemical investigations of gangrenous mastitis in does: immunological responses and oxidative stress biomarkers. J Zhejiang Univ Sci B. 14(1): 33-39.

[12] Ribeiro, M. G., Lara, G. H. B., Bicudo, S. D., Souza, A. V. G., Salerno, T., Siqueira, A. K., Geraldo, J. S. (2007). An unusual gangrenous goat mastitis caused by Staphylococcus aureus, Clostridium perfringens and Escherichia coli co-infection. Arq Bras Med Vet Zootec. 59(3):810-812. Doi: 10.1590/S0102-09352007000300037.

[13] Ameh, J. A., Addo, P. B., Adekeye, J. O, Gyang, E. O, Teddek, L. B and Abubakar, Y. (1994): Gangrenous caprine coliform mastitis. Small Ruminant Research, 13(3):307-309.

[14] Sordillo, L. M. 2005. Factors affecting mammary gland immunity and mastitis susceptibility. Livestock Production Sciences. 98:8899.

[15] Aitken, S. L, Corl C. M, Sordillo L. M. (2011). Immunopathology of mastitis: insights into disease recognition and resolution. J Mammary Gland Biol Neoplasia. 16 (4):291-304. Doi: 10.1007/s10911-011-9230-4.

[16] Sordillo, Lorraine M. G. A. Contreras and Stacey L. Aitken (2009). Metabolic factors affecting the inflammatory response of periparturient dairy cows. Animal Health Research Reviews, 10, pp 53-63. doi:10.1017/S1466252309990016.

[17] Jain, N. C. (1993): Essentials of Veterinary Hematology. Lea and fiebiger, Philadelphia; 19-40.

[18] Byers, S.R and Kramer, J.W. (2010): Normal hematology of sheep and goat: In Schalm's Veterinary Hematology. Douglas and Wardrop, K. J (eds). John Wiley and Sons, U.S.A. Sixth Edition, pp 836-840.

[19] Capuco, A. V., Paape, M. J and Nickerson, S. C. (1986). In vitro study of polymorphonuclear leukocyte damage to mammary tissues of lactating cows. Am J Vet Res. 47 (3):663-668.

[20] Miller, J. K., Brzezinska-Slebodzinska, E and Madsen, F. C. Oxidative stress, antioxidants, and animal function. J Dairy Sci. 1993; 76(9):2812-2823. Doi: 10.3168/jds.S0022-0302 (93)77620-1.

[21] Kehrli, M. E., Jr, Shuster D. E. (1994).Factors affecting milk somatic cells and their role in health of the bovine mammary gland. J Dairy Sci.; 77(2):619-627. Doi: 10.3168/jds.S0022-0302 (94)76992-7.

[22] Leone, T. A. and N. N. Finer. 2006. Foetal adaptation at birth. Current Paedia. 16:373-378.

[23] Kumar, G. S., PKR. Lyer, M. C prass7d and AK Sharma (1994). Tuberculosis in cattle; Haematological studies. Indian J. Vet. Path. 18: $38-42$.

[24] Coles, E.H. (1980): Veterinary Clinical Pathology. Third Edition. W.B.Saunders Company, Philadelphia. pp 15-121.

[25] Jenness, R.(1980). Composition and Characteristics of Goat Milk: Review 1968-1979. Journal of Dairy Science. 63 (10): 16051630 .

[26] Raynal-Ljutovac, K. G. Lagriffoul, P. Paccard, I. Guilleta and Y. Chilliard. (2008). Composition of goat and sheep milk products: An update. Small Ruminant Research 79: 57-72.

[27] Alberghina D, Casella S, Vazzana I, Ferrantelli V, Giannetto C and Piccione G. (2010). Analysis of serum proteins in clinically healthy goats (Capra hircus) using agarose gel electrophoresis. American Society for Veterinary Clinical Pathology. 39: 317-321. Doi: $10.1111 /$ j.1939-165X.2010.00226.x 
[28] Bozhkova, G and Tsvetkov, A (1976): Biochemical and cytological changes in the milk and blood of cows with subclinical mastitis. Vet Med Nauki, 13(10):74-79.

[29] Gonzalez, H.D.F., Tecles, F., Martinez-Subiela, S., Tvarijonaviciute, A, Soler, L and Ceron, J. J. (2008): Acute phase protein response in goats. Journal of Veterinary Diagnostic Investigation, 20(5):580-584.

[30] Kaneko, J. J., Harvey, J. W and Bruss, M (1997): Clinical Biochemistry of Domestic Animals. Gulf Professional Publishing, Fifth Edition, pp 495-499.

[31] Latimer, K. S., Mahaffey, E. A and Prasse, K. W. (2003): Duncan and Prasse's Veterinary Laboratory Medicine: Clinical pathology, fourth edition. Blackwell publishing 2121 state avenue, Iowa.p-136-138. 